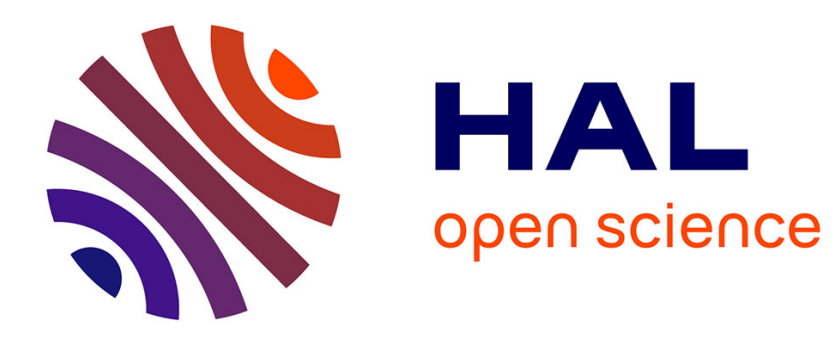

\title{
Banks as accelerators of the circulation of money
}

Laurent Le Maux

\section{To cite this version:}

Laurent Le Maux. Banks as accelerators of the circulation of money. Eastern Economic Journal, 2015, 41 (4), 10.1057/eej.2014.75 . hal-01397044

\section{HAL Id: hal-01397044 \\ https://hal.science/hal-01397044}

Submitted on 19 Nov 2016

HAL is a multi-disciplinary open access archive for the deposit and dissemination of scientific research documents, whether they are published or not. The documents may come from teaching and research institutions in France or abroad, or from public or private research centers.
L'archive ouverte pluridisciplinaire HAL, est destinée au dépôt et à la diffusion de documents scientifiques de niveau recherche, publiés ou non, émanant des établissements d'enseignement et de recherche français ou étrangers, des laboratoires publics ou privés. 


\title{
Banks as accelerators of the circulation of money
}

\author{
Laurent LE MAUX* \\ February 2015
}

\begin{abstract}
The money multiplier approach asserts that banks are unique in that they implement a creation of money, while the finance approach regards banking institutions as financial intermediaries among others. In retrospect, Cantillon's Essai stands between these two extreme approaches. It both challenges the money multiplier approach and grants to banks a significant monetary role. The aim of the paper is to clarify Cantillon's theoretical propositions on bank issuing of debts convertible on demand into money at face value and to explore further the proposition according to which banks contribute to accelerating the circulation of money.
\end{abstract}

During the last century, the quantity theory, Old view, and monetarism developed the money multiplier approach and maintained that commercial banks are unique among financial institutions in that they increase the quantity of money at will, and, all things considered, act as creators of money (Fisher, 1911; Friedman, 1959; Pesek and Saving, 1968). Since the New view and the integration of banking in the theory of finance, the pendulum has swung to the opposite extreme (Gurley and Shaw, 1960; Tobin, 1963; Fama, 1980). Banks are henceforth considered by contemporary banking theory as financial intermediaries among others and their monetary role has been denied.

* Professor in economics, University of Brest and University of Paris Saint-Denis, France. The present paper will be published in the Eastern Economic Journal, 41(4), 2015. 
An alternative approach standing between these two extreme views was suggested almost 300 years ago. Retrospectively, in his Essai sur la Nature du Commerce en Général, Richard Cantillon at one and the same time challenges the money multiplier approach and grants to banks a significant monetary role. ${ }^{1}$ The Essai propounds a twofold theoretical proposition on bank issuing of debts convertible into money, at face value, to the bearer, and on demand. The first proposition is the law of reflux in the form of convertibility, which means that banks cannot issue more than demand debts that the public wants to hold. The first proposition was restated by classical monetary theorists in the late eighteenth and nineteenth centuries, and has been documented by the secondary literature (Skaggs, 1991; Glasner, 1992; Le Maux, 2012). The second proposition, connected to the first, states that banks contribute to accelerating the circulation of money through the issue of demand debts and then considers banks as accelerators of the circulation of money. The second proposition is a very particular contribution from Cantillon to monetary and banking theory. I shall refer to it as the "banking approach of circulation" (regarding banks as accelerators of the circulation of money) in opposition with the "quantity approach of banking" or "money multiplier approach" (viewing banks as creators of money). ${ }^{2}$

Cantillon's banking approach of circulation has been largely overshadowed by the Old and New views and is rarely mentioned in literature. Without any explicit reference to the Essai, Wicksell $(1898,1906)$ expounds a similar proposition when he deals with the "virtual" acceleration of money. Nevertheless, as will be seen, Wicksell's analysis is too broadly formulated, encompassing all manner of credit and not specifically bank credit. However, the term "virtual" is the most appropriate and I shall adopt it to designate the accelerated circulation of money brought about by banks. Later, Holtrop (1929, pp. 506-7) and Rist (1938, pp. 38-9, pp. 69-71) point out the importance of Cantillon's banking approach of circulation and link it with the idea of the virtual velocity of circulation formulated by Wicksell. In subscribing to the money multiplier approach, Schumpeter (1954, pp. 319-21) is maybe the sole who explicitly endeavors to refute Cantillon's proposition. Within the quantity theory, Allais (1987, pp. 533-4) criticizes Rist's - in fact Cantillon's-view, which considers "that the credit mechanism does not lead to the money creation, and that its only effect is to increase the velocity of circulation of basic money. [...] Mathematically, the two formulations are equivalent, but only the [quantity] interpretation is of real significance in terms of economic understanding." This Allais's statement is precisely open to discussion.

Before beginning the substantive discussion, two definitions-explicitly or implicitly given in the Essai - need to be emphasized. First, by money, Cantillon means the silver or gold specie coined at an official price at the 
Mint. Nowadays, the ultimate money is not specie but the inconvertible liabilities issued by the central bank- the fiat money. Cantillon did not refer to the fiat money standard when expounding the banking approach of circulation, but let us keep in mind that his proposition is independent on whether money is metallic or fiat. As a second definition, a bank is a fractional reserve institution holding money in reserve and, thus, an institution issuing demand debts such as banknotes or demand deposits convertible at face value into money and partially backed by it. Theoretically, Cantillon argues that the form of demand debt is irrelevant and it is only a practical matter (Essai, p. 305) and, most importantly, he draws a clear-cut distinction between money and demand debts. These definitions have been rediscovered by Rolnick and Weber (1997, p. 1311) and imply "that money should be divided into two mutually exclusive categories: objects that represent a convertibility promise by, or claim on, the issuer and objects that represent no convertibility promise or claim. For convenience, we refer to the nonconvertible, unclaimed objects as primary money, and the convertible, claimable objects as secondary money" (original italics). Respectively, I refer to money and demand debts.

In order to discuss the monetary role of banking, the present paper briefly comes back to the law of reflux first held by Cantillon and contrasts it with the quantity approach of banking. Then, it specifies two kinds of circulation drawn by Cantillon termed here the "monetary approach of circulation," which is related to the physical circulation of money, and the "banking approach of circulation," which is related to the virtual circulation of money. Furthermore, two channels of virtual circulation of money provided by banks are considered, namely "externalization" and "internalization," and their characteristics concerning the liquidity risk borne by banks. Finally, the paper provides an analysis of comments on Cantillon's banking approach of circulation.

\section{CONSTRAINT OF CONVERTIBILITY AND LIQUIDITY}

The Essai describes the banking activities and their implications. On the one side, bankers credit accounts or put notes "payable on demand" into circulation for economic agents who deposit specie with them "to avoid the trouble of keeping this money in their houses and the thefts which be made of it" (Essai, p. 299). On the other side, bankers go beyond the simple service of keeping specie in their vaults: they lend money, or extend credit by issuing demand debts. This credit-granting activity is connected with the law of reflux or the adverse clearing mechanism. Cantillon essentially mentions reflux in the form of demand for convertibility of banknotes into specie and shows how competing issuing banks are compelled to reimburse 
every note in excess. The convertibility constraint makes over-issuing ruinous for any expansionist bank, because over-issues involve marginal costs that exceed gains, indicating to the bank that the issues exceed the demand for them. In Cantillon's words, bankers "will be ruined in credit if they fail for one instant to pay their notes on their first presentation, and when they are short of cash in hand they will give anything to have money at once, that is to say a much higher interest than they receive on the sums they have lent" (Essai, p. 303).

It is not just the public who ask for notes they do not wish to hold to be redeemed. Rival banks and the banking community as a whole also impose discipline in the matter of bank issues. In effect, if notes issued by a banker "fall into the hands of persons who are not accustomed to deal with him," they stay in circulation for longer and this "delays his payments a few days or weeks"; by contrast, if "his notes come into the hands of those of his own business," these rival bankers "will have nothing more pressing than to withdraw the money from him" (Essai, p. 303). The reflux is fast enough taking only a few "weeks" at most for convertible banknotes (more generally, for demand debts) not to become overabundant, and not to have any inflationary effect. Accordingly nowhere does the Essai state that demand debts could affect prices. In addition, the above-quoted passages introduce two important and interlinked theoretical features of banking: first, the adverse clearing mechanism which involves the collection of rival banknotes, the gross (or possibly net) clearings, and then the demand for settlements; second, an explanation of the velocity of the reflux of demand debts that is clearly distinct from the velocity of the circulation of money as a stock. In sum, the problem is not one of the quantity of money or any monetary aggregate potentially in excess, but fundamentally one of liquidity — and as the ultimate liquidity, money alone is the "true sinews of circulation" (Essai, p. 319).

Hence, Cantillon's analysis is inconsistent with the quantity approach of banking, which rests on ( $($ ) the aggregate of "base money" (whether metallic or fiat) and "bank money," (ii) the money multiplier linking the two, and (iii) the twofold postulate of proportionality and causality applied to this aggregate. It is different from the Old view, which considers that commercial banks are "unique" among financial institutions because they are able to "produce money" through the multiplier approach just like a miner "produces some ounces of gold" (Pesek and Saving, 1968, pp. 144, 150). It may be added that Cantillon's view also differs from the New view, which argues that banks are pure intermediaries and their function as such is to satisfy the portfolio preferences, and that the differences between banks and other financial intermediaries "are of degree, not of kind" (Tobin, 1963, p. 418). In attempting to reconcile Old and New views, Selgin $(1989$, p. 84) points out that exponents of the New view do not state their 
theory in a manner consistent with the view that "banks face a liquidity constraint and that they will expand their liabilities until this constraint becomes binding." Actually, this liquidity constraint view begins with the Essai.

As I shall detail, according to Cantillon, banks are intermediaries (they issue debts that agents want to hold to some extent and, against these, they grant loans or purchase assets) but of a special kind: their debts are so particular (they are redeemable on demand and at face value in money) that they have a derived and a specific monetary function (banks accelerate or decelerate the circulation of money) that entails a specific risk (that is, the liquidity risk occurring at any time, and not only the transformation occurring at maturity).

\section{MONETARY AND BANKING APPROACHES OF CIRCULATION}

Cantillon expounds two distinct approaches, which pertain to the circulation of money. The first - called here the "monetary approach of circulation"-is familiar enough and taken up by the Fisherian analysis. It postulates that "an acceleration or greater rapidity in circulation of money in exchange, is equivalent to an increase of actual money up to a point" (Essai, p. 161). Just like an increase in the quantity of money, an increase in the velocity of money helps to realize new transactions. It is a monetary concept insofar as it can be suggested without any reference to banks' issuing activity, but to money alone. It contributes to speeding up the physical circulation of money. No bank need necessarily intervene. Several factors may speed or slow the physical circulation of money: economic and geographical spheres of exchange, hoarding, precautionary motives for holding money (Essai, pp. 142-7), and a credit instrument: drawing of bills.

The drawing and clearing of bills of exchange contributes to economizing circulation and corresponds to a physical acceleration of money. Indeed, Cantillon (Essai, p. 141) states that offsetting between merchants-which he calls "exchanges by valuation"-seem "to economise much cash in circulation, or at least to accelerate its movement, by making it unnecessary in several hands through which it would need to pass without this confidence and this method of exchange by valuation." For a given volume of transactions, merchants need less money. Cantillon (Essai, p. 177) returns a contrario to the effects of clearing: when purchases are no longer "made by valuation" (by clearing) and are instead "made for cash" (by physical circulation), there is a need for "greater rapidity in the circulation of money" from place to place. As a result, the physical acceleration of money compensates for the discontinuance of the practice of clearing. In dealing further with the issuing and clearing of bills, Cantillon 
(Essai, pp. 227-9, 247-51) repeats that "by exchange or set-off [...] the trouble of sending money from one city to the other" will be saved, the "double transaction or transport may be avoided."

The technique of demand-debt issues by banks is different from those of the drawing and clearing of bills of exchange. It "also" (Essai, p. 141) contributes to speeding up the circulation of money, not by avoiding physical circulation, but by carrying out virtual acceleration. This brings us to the second approach of circulation - called here the "banking approach of circulation." It is essentially a banking feature and pertains to banks in that they are exclusively concerned. It states that banks accelerate the circulation of money through the issuing demand debts. In Cantillon's words: "The bankers and goldsmiths contribute to accelerating the circulation of money. They lend it out at interest at their own risk and peril, and yet they are or ought to be always ready to cash their notes when desired on demand" (Essai, p. 301, italics added; see also, pp. 141-3). The distinction between money (here, specie) and demand debts (here, banknotes) stands for a precise articulation between them inasmuch as demand debts accelerate the circulation of money. The outcome that derives from the acceleration of the velocity of money by banks is that they bear both a credit risk (banks lend "at interest at their own risk and peril") and a liquidity risk (they have to reimburse their issues "when desired on demand"). Finally, the banking approach of circulation (regarding banks as accelerators of the circulation of money) is related with the law of reflux (regarding banks as a fractional reserve institution bearing convertibility constraint).

By the monetary approach of circulation, the circulation of money is external in that the fraction of money held by the public physically circulates outside the bank. In contrast, by the banking approach of circulation, the circulation of money is internal in that the other fraction of money not circulating among the public remains inside the vaults of the banking system; the circulation is also virtual in the sense that the fraction of money held by banks does not circulate physically. And yet, through the banking approach of circulation, money circulates as if monetary approach of circulation were operative: money is not actually circulating among the public, but new transactions may be made just the same. In sum, the virtual acceleration (deceleration) of velocity of money is effective when the banks put into (withdraw from) circulation demand debts in supplying (in asking for reimbursement of) bank credit.

One consideration must be stressed at this stage. The virtual aspect of the banking approach of circulation makes sense only under the fractional reserve banking system. It is fundamentally linked with the fact that several agents who routinely use demand debts as means of payment in place of money consider the same amount of money held by the issuing bank in reserve as immediately available. This characteristic is effective in the case 
of demand debt issuance, but not in the case of issuance of time obligations such as commercial papers, bills, securities, or even time deposits. In the latter cases, only the creditor (and not several) considers that money is available only at maturity (and not at demand). This fundamental point helps to differentiate clearly drawing of bills from demand-debt issue. Nonetheless, such a distinction is not clear or apparent in Wicksell's writings on circulation. Wicksell (1906, p. 67) lays down the idea of "virtual" circulation of money as opposed to a purely "physical" one, but he applies the virtual character of accelerated circulation to all forms of debts, whereas Cantillon restricts it to demand-debt issuing by banks.

Indeed, Wicksell (1906, p. 67) contends that the "influence of credit" on money may "under all circumstances" be regarded as virtually accelerating the circulation of money (italics original). In such a perspective, the time obligations issued by non-bank agents or financial intermediaries is placed on the same footing as demand debts issued by banks. In the case of pure intermediation, for instance, Wicksell (1898, pp. 62-3, 66) supposes that "the use of bills of exchange" and "centralization of lending in the banks (or on the bourse)" are equivalent as regards their effects on circulation. In the case of ordinary trade bills not discounted at a bank, circulating as a means of payment among merchants, and possibly being set off, Wicksell (1906, p. 70) concludes that "[h]ere also it may be said that the velocity of circulation has been virtually accelerated."

The main criticism that may be made on these Wicksell's contentions is that not all forms of credit bring about a virtual acceleration of money. Let us detail the different cases. In the case of commercial or financial clearing, and as seen previously, the economizing of circulation through clearing corresponds to a physical and not a virtual acceleration of money. In the case of discount or simple credit, one agent (the creditor) considers an amount of money available only at maturity (the debtor considers as available until maturity the same amount that he does not have to lay out immediately) and this entails no virtual character of circulation. In the case of pure intermediation, the financial institution does not keep any money in reserve and only transforms the maturity of time deposits or savings that the public entrusts to it. By contrast, in the case of bank issuing activity, several agents at the same time consider as immediately available the same amount of money as the bank keeps in its vault.

Finally, in the case of demand debts (banknotes as well as deposits convertible at demand at face value into money), and only in this case, Wicksell (1906, p. 68) perfectly echoes Cantillon's banking approach of circulation: "The [physical] circulation of the notes outside the bank may thus be regarded as a virtual [...] circulation of coins lying in the bank's keeping" (italics original). 


\section{THE VIRTUAL CIRCULATION OF MONEY}

Once the Cantillon's banking approach of circulation has been scrutinized, it is possible to detail two different channels cut by the fractional reserve system and by which money can circulate virtually. The first channel, termed here "externalization" of circulation, consists of credit granted by banks in putting into circulation money previously held by the bank. There is a cash withdrawal up to the amount of credit, a transfer of money from the bank to the public that involves a transformation of bank asset maturity. The bank, to the detriment of its own reserve holding, increases the amount of money held by the public, which can therefore make new transactions. Externalization is such that "the banker will often be able to lend 90,000 ounces [of silver] of the 100,000 he owes throughout the year and will only need to keep in hand 10,000 ounces to meet all the withdrawals. [...] As fast as one thousand ounces are demanded of him in one direction, a thousand are brought to him from another. It is enough as a rule for him to keep in hand the tenth part of his deposits" (Essai, pp. 299-301). It can be noted here the idea that the fractional reserve system is sustainable since the efflux and the reflux of liquidity inside the bank are equivalent over a given period of time. This theoretical outcome explains bank debt sustainability-a contrario bank liquidity crises - and also holds for the second channel.

The second channel of the banking approach of circulation, termed here "internalization," consists of a credit granted through the issuing of demand debt up to the amount of credit, and it also entails a disequilibrium between asset and liability maturity. The bank varies its reserve ratio, not by decreasing its reserve, but by increasing the amount of its demand obligations. In other words, internalization is based on (i) the bank credit through the issuing of demand debts and (ii) the circulation of such debts instead of money-so long as they are convertible. "The goldsmiths and public bankers, whose notes pass current in payment like ready money, contribute also to the speed of circulation, which would be retarded if money were needed in all payments for which these notes suffice" (Essai, pp. 141-3, italics added; see also p. 305, about public banks). In this significant passage, the distinction between money and banknotes is not only descriptive but also analytical: demand debts accelerate the circulation of money, which would be delayed if they were not issued.

One or the other channel of virtual circulation of money is, for a supplementary level of transactions, more or less efficient depending on whether it makes the bank more or less vulnerable to liquidity risk. Three modes of circulation may be identified in order to understand their consequence on bank liquidity risk. First, as seen above, "externalization" 
consists of bank credit such as the amount of money held by the bank decreases with nominal transactions and that held by public increases in consequence. Second, "partial internalization" is similar to externalization insofar as a substantial proportion of money continues to circulate among the public; but it differs from externalization insofar as the bank supplies credit by issuing demand debts and not by withdrawing money. Third, "complete internalization" relies on a more sophisticated payment system than in partial internalization inasmuch as money is very largely (almost completely) centralized in the bank vaults; bank reserves are practically equivalent to the total stock of money and very little (if any) money circulates outside. Thus, the virtual circulation allowed by each mode generates a different liquidity risk for a supplementary level of transactions and for given credit and asset risks. Because of an absence of demand debts issue (that is, because of a money withdrawal, which de facto involves lesser centralization), the liquidity risk is higher with externalization mode than with partial internalization mode. And because of a less centralization of money at the bank, the liquidity risk is higher with partial internalization mode than with complete internalization mode.

Such a categorization brings about that institutional characteristics of the payment system, including (i) demand-debt issuing by banks, (ii) broad acceptability of this demand debt among the public, and (iii) extensive or complete centralization of money at the banks or at the central bank, are crucial. They have direct consequences for liquidity-risk management and reinforce public confidence in the payment system. And it is in this way that we might understand Cantillon (Essai, p. 305) when he writes that: "A general national bank has this advantage over the bank of a single goldsmith that there is always more confidence in it. The largest deposits are willingly brought to it." Demand-debt issuance associated with extensive centralization of money leads to a more efficient payment system: the circulation of money and its acceleration are thus mainly internalized by banks, and the liquidity risk is lower for a given level of transactions; in other words, for a given liquidity risk, a bank can make possible a higher level of transactions.

At this stage, two considerations are in order. The first is that a definition of the virtual acceleration of money through internalization could be given a contrario. If the demand debts $(D)$ correspond to the totality of money that the bank holds in reserve $\left(M_{b}\right.$ with $\left.M_{b}=D\right)$, they circulate as if the money held by the bank circulates among the public. Consequently, the velocities of circulation of $M_{b}$ and $D$ (respectively, $v_{b}$ and $v_{d}$ ) are similar $\left(v_{b}-v_{d}=0\right)$. No acceleration of money can take place within the banking system. Now, if the bank is a fractional reserve institution (with $M_{b}<D$ ), and if its demand debts circulate as money, then the velocity of money exceeds 
the velocity of demand debts. The ensuing virtual acceleration of money can be measured by the difference between these two velocities $\left(v_{b}-v_{d}>0\right)$. The second consideration importantly pertains to the price level. Because of the constraint of the law of reflux, the issue of demand debts cannot be overabundant. Correlatively, the virtual acceleration of money cannot be "in excess" or inflationary. Inasmuch as the demand for demand debts expressed by agents corresponds to a demand for an increase in the velocity of money, the velocity of circulation remains similar to that demanded. In other words, the law of reflux helps to equalize the "supply" of acceleration by banks and the "demand" for acceleration by the public, without entailing inflationary effect.

\section{COMMENTS IN LITERATURE AND DEVELOPMENTS}

Cantillon's banking approach of circulation is not plainly appraised in literature. Schumpeter's History of Economic Analysis is an exception and interestingly endeavors to refute it. One argument is based on the example of a "check-room attendant" of a theater who rents out the coats deposited with him-an example, it can be noticed, which only applies to the externalization channel. It is then supposed that this attendant "is a wizard, and performs the feat of making it possible for two people, the owner and the hirer, to wear the same coat at the same time" (Schumpeter, 1954, p. 320). This case is such that, two persons wearing the same coat at the same time, the attendant would duplicate coats just like bank would multiply money. This is precisely the conclusion of the money multiplier or money creation approach. In this respect, it is not surprising, even significant, that Fisher $(1935$, p. 42$)$ comes to consider a bank as being "able to perform a miracle." Another case must be considered. There is in fact a rental service of coats with a very particular technology namely, fractional backing of the coat deposits. The attendant does not rent a coat that he buys himself and which belongs to him, but he rents a coat, which has been entrusted to him for a time, while its owner is in the auditorium. If he succeeds in anticipating the return of the coat (by the hirer) and the withdrawal of the coat (by its owner or the initial depositor), our attendant brings into effect (by the technique of a fractional reserve system) an acceleration of the velocity of the coat that, instead of being in the cloakroom, is on the back of a hirer-stroller during the time of the concert. No miracle, but a supplementary circulation of the coat through externalization.

A further argument from Schumpeter (1954, p. 320) shows the difficulty in describing virtual circulation in concrete terms and, faced with this stumbling block, he comes to the idea that it might "perhaps, seem more natural to say that bankers increase not the velocity but the quantity of 
money"-and here Schumpeter seems to turn over a new leaf- "or of those means of payment that, within limits, serve as well as money." But the idea that the banks issue means of payment such as demand debts does not dismiss that the banks increase the velocity of circulation of money: on the contrary, the former generates the latter. However, Schumpeter maintains, in accordance with the money multiplier approach, that banks "create" deposits or banknotes and "appear to manufacture money rather than to increase its velocity." And this petitio principii collapses when Schumpeter asserts that "it is clear and actually beyond dispute that what the banker does with money cannot be done with any other commodity"; and that "there is no other case in which a claim to a thing can, within limits to be sure, serve the same purpose as the thing itself"; and, as an illustration, that "you cannot ride on a claim to a horse" (Schumpeter, 1954, pp. 320-1).

These assertions are open to various - three at least - rebuttals. The first is that the example of the "claim to a horse" is misapplied. In effect, a commodity can be defined as a good not subjected to minting and circulating at a monetary price. It can be used for production purposes or for consumption. Or it can circulate as a mean of payment. Whichever the case, the concept of circulation is effective both for money and for commodities in the productive and commercial process. By contrast, a service cannot circulate because, by definition, it is destroyed since it is used. There is thus an analytical shift in the example presented by Schumpeter that makes it inappropriate: riding a horse corresponds to a service (transportation or leisure) and not to a commodity (a horse). The reasoning must be made with a horse, a bundle of wheat, or a coat as a commodity, and not as a vector of a service.

The second rebuttal reverses Schumpeter's assertion that "what the banker does with money cannot be done with any other commodity." In fact, a bank actually cannot increase the quantity of any other commodity just as it cannot increase the quantity of money. Hence, the idea that a bank cannot increase either the quantity of a commodity or the quantity of money refutes ex abrupto the money multiplier approach or the quantity approach of banking. It even strengthens the consistency of the alternative approach, namely, Cantillon's banking approach of circulation. If a bank does not increase the quantity of what it is held in reserve, money or any good, the alternative hypothesis is to consider that the bank increases the velocity of what it is held in reserve, money or any good. This leads to the third rebuttal: a fractional reserve institution can also increase the velocity of circulation of a commodity and, consequently, a bank as a fractional reserve institution can do with any commodity (banking in good) what it does with money (banking in money).

To resume this third issue, imagine a market where a commodity, say wheat, is negotiated and circulates. Agents put the wheat in an institution, a 
warehouse, which reduces transportation and transaction costs. The warehouse issues certificates in order to testify to the deposits of wheat, and these certificates circulate between brokers and merchants in place of the bundles of wheat. As the price for immediate delivery is higher than the price for future delivery, especially when storage and insurance costs are taken into account, the issuance of extra warehouse certificates may be profitable and effective. Thus, the warehouse becomes a fractional reserve institution holding one kind of commodity (and not money) in reserve. Historically, the rice warehouses in Japan in the seventeenth century (Crawcour, 1961) and the warehouses in Chicago on the wheat market in the late nineteenth century (Williams, 1984) implemented such practice of credit on the basis of commodity deposits. Williams (1984, pp. 491-2) clearly shows how the warehouse could proceed by internalization as by externalization. According to the banking approach of circulation, the warehouse increases the velocity of circulation of rice or wheat and by no means increases their quantity. Therefore, as an institution issuing demand debts, a fractional reserve institution such as a bank can possibly do with any commodity what it already does with money — and a warehouse can possibly do with money what it already does with wheat. It must be emphasized that wheat does not become any kind of money: even though it circulates as a means of payment through certificates issuance, it remains a commodity with a monetary price.

Accelerating the velocity of commodities is more costly for the reason that a separate kind of fractional reserve institution is necessary for each type of commodity, for each market. And, because money is the means of payment unanimously accepted by the community, one can understand how its acceleration by fractional reserve institutions is so useful and helps the community to make new transactions. Demand for the virtual acceleration of money being higher than demand for the virtual acceleration of commodities, one can also apprehend why banks are the most important and largest fractional reserve institutions. In other words, just as money is the unanimously accepted means of payment, the virtual acceleration of money is a service commonly asked for, which explains the massive development of banks compared with other fractional reserve institutions.

\section{CONCLUSION}

Cantillon's banking approach of circulation according to which banks accelerate the circulation of money and by no means multiply its quantity is not limited to the metallic standard. More generally, it is relevant since there is convertibility of demand debts at face value into money, which may be metallic (specie money coined at the Mint) or fiat (inconvertible money 
issued by the Treasury or the central bank). Today's fiat money regime is different from that prevailing in Cantillon's time, but the banking approach of circulation can apply to demand deposits issued by commercial banks: through the issuance of demand debts convertible into central bank money, commercial banks help to virtually accelerate its circulation. The banking approach of circulation is no longer operative with regard to central bank money not convertible into outside money: central bank can sovereignly increase the quantity of fiat money. The banking approach of circulation might, however, be helpful in understanding the function of the central bank under a regime of convertibility into metallic money. The case investigated in this paper concerns demand debts issued, and money reserves held by individual banks. Another case may concern high-powered mediums issued by the central bank and specie reserve that it centralizes in its vaults: it therefore imply the action of the central bank as a lender of last resort under the specie regime. Interestingly, the Essai ends with a description of the phenomenon of sauve qui pent ${ }^{3}$ during a panic.

\section{NOTES}

1. Richard Cantillon's Essai sur la Nature du Commerce en Général (hereafter, Essai) was written around 1730 but first published in Paris only in 1755. The English translation I shall use is Higgs' edition published in 1931 (Cantillon, 1755 [1931]). On the Cantillon's monetary theory, readers might like to refer to Holtrop (1929), Hayek (1931), Schumpeter (1954), Bordo (1983), Murphy (1986), Niehans (1987).

2. The quantity approach of banking was first held by David Hume (1752 [1985]). For a synthetic view of Hume's monetary thought, see Wennerlind (2005, 2008), Schabas and Wennerlind (2011). For a comparison of the Cantillon's Essai and the Hume's Discourses on money and banking, see Le Maux (2014).

3. In the 1755 edition of the Essai (p. 322), one can read the curious expression "on en viendrait à crever la bombe" — translated by "the bomb would burst" in Higgs's edition (p. 323). Mirabeau's manuscript corrects this in using the expression "on en viendrait à sauve qui peut." See INED edition of the Essai (Cantillon, 1755 [1952], note 1, p. 173) and Salleron (1952, p. lxvi). The French expression sauve qui peut means "every man for himself." 


\section{REFERENCES}

Allais, Maurice. 1987. The Credit Mechanism and its Implications, in Arrow and the Foundation of the Theory of Economic Policy, edited by George R. Feiwel, 491-561. Basingstoke : Macmillan.

Bordo, Michael D. 1983. Some Aspects of Monetary Economics of Richard Cantillon. Journal of Monetary Economics 12(2): 235-258.

Cantillon, Richard. (1755) 1931. Essai sur la Nature du Commerce en Général, edited by H. Higgs, London: Macmillan.

Cantillon, Richard. (1755) 1952. Essai sur la Nature du Commerce en Général. Paris: Institut National d'Etudes Démographiques.

CRAwCOUR, Sydney. 1961. The Development of Credit System in $17^{\text {th }}$ Century Japan. Journal of Economic History, 21(3): 342-360.

FAMA, Eugene F. 1980. Banking in the Theory of Finance. Journal of Monetary Economics, 6(1): 39-57.

FISHER, Irving. 1911. The Purchasing Power of Money. New York: Macmillan.

FISHER, Irving. 1935. 100\% Money. New York: Adelphi Company.

Friedman, Milton. 1959. A Program for Monetary Stability. New York: Fordham University Press.

GlasNer, David. 1992. The Real-Bills Doctrine in the Light of the Law of Reflux. History of Political Economy, 24(4): 867-894.

GurLEY, John G., and Edward S. SHAw. 1960. Money in a Theory of Finance. Washington DC: Brookings Institute.

HAYEK, Friedrich A. (1931) 1985. Richard Cantillon. Introduction of the German translation of the Essai, Jena: Fischer. Journal of Libertarians Studies, 7(2): 217-247.

Holtrop, Marius W. 1929. "Theories of the Velocity of Circulation of Money in Earlier Economic Literature. Economic History, Supplement to the Economic Journal, 4(January): 503-524.

Hume, David. (1752) 1985. Political Discourses, in Essays, Moral, Political, and Literary, edited by Eugene F. Miller, Indianapolis: Liberty Fund.

LE MAUX, Laurent. 2012. The Banking School and the Law of Reflux in General. History of Political Economy, 44(4): 595-618.

LE MAuX, Laurent. 2014. Cantillon and Hume on Money and Banking: The Foundations of Two Theoretical Traditions. Journal of Economic Surveys, 28(5): 956-970.

MURPHY Antoin E. 1986. Richard Cantillon: Entrepreneur and Economist. Oxford: Oxford University Press.

NieHANs, Jürg. 1987. Richard Cantillon and sein "Essai". Düsseldorf: Verlag Wirtschaft und Finanzen.

PeseK, Boris P., and Thomas R. SAVING. 1968. The Foundations of Money and Banking, New York, Macmillan.

RisT, Charles. (1938) 1940. A History of Monetary and Credit Theory from John Law to the Present Day. London: Macmillan. 
Rolnick, Arthur J., and Warren E. Weber. 1997. Money, Inflation, and Output under Fiat and Commodity Standards. Journal of Political Economy, 105(6): 1308-1321.

Schabas, Margaret, and Carl Wennerlind. 2011. Hume on Money, Commerce, and the Science of Economics. Journal of Economic Perspectives, 25(3): 217-230.

SCHUMPETER, Joseph A. 1954. History of Economic Analysis. London: Allen and Unwin.

SELGIN, George A. 1989. Commercial Banks as Pure Intermediaries: Between 'Old' and 'New' Views. Southern Economic Journal, 56(1): 80-86.

SkAGGS, Neil T. 1991. John Fullarton's Law of Reflux and Central Bank Policy. History of Political Economy, 23(3): 457-480.

TOBIN, James. 1963. Commercial Banks as Creators of 'Money', in Banking and Monetary Studies, edited by Deane Carson, 408-419. Irwin: Homewood.

WennerLIND, Carl. 2005. David Hume's Monetary Theory Revisited: Was He Really a Quantity Theorist and an Inflationnist? Journal of Political Economy, 113(1): 223-237.

Wennerlind, Carl. 2008. An Artificial Virtue and the Oil of Commerce: A Synthetic View of Hume's Theory of Money, in David Hume's Political Economy, edited by Margaret Schabas and Carl Wennerlind, 105-126. London: Routledge.

WiCKSELL, Knut. (1898) 1936. Interest and Prices. London: Macmillan.

WickselL, Knut. (1906) 1935. Lectures on Political Economy-Money. London: Routledge and Kegan.

Williams, Jeffrey C. 1984. Fractional Reserve Banking in Grain. Journal of Money, Credit and Banking, 16(4): 488-496. 